\title{
Original Paper \\ Orchids of the central region of eastern Maranhão, Brazil
}

\author{
Miguel Sena de Oliveira ${ }^{1,5,6}$, Alessandro Wagner Coelho Ferreira ${ }^{2}$, Hermeson Cassiano de Oliveira ${ }^{1,3}$ \\ \& Edlley Pessoa ${ }^{1,4}$
}

\begin{abstract}
The eastern portion of the state of Maranhão is a transitional area between Amazon Rainforest, Cerrado and Caatinga. Knowledge about the flora of this region is very poor, especially regarding Orchidaceae. The aim of this study was to provide a survey of the species of this family in the central area of this region. Fieldwork was performed monthly between December 2015 and April 2019 in the municipalities of Aldeias Altas, Caxias, Codó and São João do Sóter. An identification key, morphological descriptions and illustrations of the species are presented. Orchidaceae is represented in the area by seven genera and 17 species. The richest genera were Catasetum (five species), and Habenaria (four species). Habenaria schenckii is a new record for the state. The majority of the species are epiphytes (eight species, $47 \%$ ) or terrestrial (seven species, $41 \%$ ). The municipality of Caxias was the richest, with 13 species (76\%), of which six were collected in the conservation units (CU's) existing in the municipality (Área de Proteção Ambiental Municipal (APAM) Buriti do Meio Municipal and APAM Inhamum). Our data highlight the importance of the CU's for the conservation of Orchidaceae, and the potential of ecotonal regions for discovering new records for the region.
\end{abstract}

Key words: Amazon, Caatinga, Cerrado, ecotone, taxonomy.

\section{Resumo}

A região leste do estado do Maranhão é uma área de transição entre a Amazônia, Cerrado e a Caatinga. Pouco se conhece sobre a flora dessa região, especialmente com relação à Orchidaceae. O objetivo desse estudo foi realizar o levantamento das espécies desta família na área central desta região. As coletas em campo foram realizadas mensalmente entre dezembro de 2015 e abril de 2019 nos municípios de Aldeias Altas, Caxias, Codó e São João do Sóter. São apresentadas uma chave de identificação, descrições morfológicas e imagens das espécies encontradas. Orchidaceae está representada na área por sete gêneros e 17 espécies. Os gêneros mais ricos foram Catasetum (cinco espécies), Habenaria (quatro espécies). Habenaria schenckii é um novo registro para a Flora do Maranhão. A maioria das espécies apresentou hábito epífitico (oito espécies, 47\%) ou terrícola (sete espécies, 41\%). O município de Caxias foi o mais rico, com 13 espécies (76\%), sendo seis destas coletadas nas Áreas de Proteção Ambiental (APAs) existentes no município (APA Municipal do Buriti do Meio e a APA Municipal do Inhamum). Os dados evidenciam a importância das Unidades de Conservação para a proteção das Orchidaceae, e o potencial das regiões ecotonais na descoberta de novos registros.

Palavras-chave: Amazônia, Caatinga, Cerrado, ecótono, taxonomia.

\footnotetext{
${ }^{1}$ Universidade Estadual do Maranhão, Prog. Pós-graduação em Biodiversidade, Ambiente e Saúde, Caxias, MA, Brazil.

${ }^{2}$ Universidade Federal do Maranhão, Depto. Biologia, São Luís, MA, Brazil. ORCID: <https://orcid.org/0000-0002-0961-5189>.

${ }^{3}$ Universidade Estadual do Piauí, Depto. Biologia, Campo Maior, PI, Brazil. ORCID: <https://orcid.org/0000-0002-1611-9562>.

${ }^{4}$ Universidade Federal do Mato Grosso, Depto. Botânica e Ecologia, Lab. Estudos Integrados de Plantas, Cuiabá, MT, Brazil. ORCID: <https://orcid.org/00000003-3800-8684>.

${ }^{5}$ ORCID: $<$ https://orcid.org/0000-0001-8931-4978>.

${ }^{6}$ Author for correspondence: miguelsena2010@hotmail.com
} 


\section{Introduction}

Orchidaceae Juss. has a cosmopolitan distribution, but is more abundant and diversified in tropical forests, especially in Southeast Asia and the Neotropics (Dressler 1993; Pridgeon et al. 1999). It is one of the largest families of Angiosperms, with approximately 28,000 species, distributed in 736 genera (Chase et al. 2015). Although greater diversity of the group is observed in wet forest areas, its species can inhabit the most varied types of vegetation, including Caatinga and Cerrado areas (Batista et al. 2005; Rodriguez et al.2009; Ferreira et al. 2010; Hall et al. 2013; Vieira \& Barros 2017; Pessoa \& Alves 2014; BFG 2018; Rodrigues et al. 2019).

Brazil stands out for its high diversity of Orchidaceae, having in its flora about 220 genera and 2,500 species (BFG 2018). The taxonomic studies conducted in Bahia (Bastos \& Van den Berg 2012; Marinho \& Azevedo 2014; Vieira et al. 2014), in Paraíba (Almeida et al. 2007), in Pernambuco (Pessoa \& Alves 2012, 2014, 2015), and in Sergipe (Pessoa \& Alves 2011; Monteiro et al. 2012) have helped improve is knowledge of Orchidaceae in the Northeast region of the country. However, some states such as Maranhão remain poorly studied from a taxonomic point of view, especially for this family, and only the list by Silva et al. (1999) is known.

The first records of Orchidaceae for the state were made by Pabst \& Dungs (1975, 1977) citing only ten species. Later, Silva et al. (1999), motivated by the fact that Maranhão is geographically in an ecotonal region among the Amazon Rainforest, Cerrado and Caatinga (Maranhão 2011), carried out the principal study of the family, concentrating mainly in the northern and western portions of the state, cataloguing 103 species of Orchidaceae, increasing considerably the number of taxa recorded. However, only a few specimens were herborized, and those that were, are deposited in the Emilio Goeldi Museum Herbarium (MG). Currently, there is no significant collection of Orchidaceae in any research institution based in Maranhão.

Some species listed by Silva et al. (1999) were only named later, since they were new taxa (Silva \& Oliveira 1999, 2000; Campacci \& Silva 2009). Currently, are registered for the state of Maranhão 52 genera and 120 species (BFG 2018; Flora do Brasil 2020).

However, there are still regions of the state lacking in botanical collections, one of them is the eastern portion of Maranhão (Maranhão 2011), where the typical vegetation is Cerrado (Stella 2011). Among the first collections of Orchidaceae recently performed in this area, Ferreira et al. (2017) published the first records of Vanilla bahiana Hoehne and $V$. pompona Schiede for the state, which indicate the lack of knowledge that this region represents. Intensive collections in eastern Maranhão are important to minimize this deficit and reveal the orchidological flora in this transition region of the Amazon-Cerrado-Caatinga.

Therefore, given the need to know the species that occur in eastern Maranhense and the few collections of Orchidaceae for the state, the objective of this research was to perform a taxonomic and floristic study of Orchidaceae for the central region of eastern Maranhão.

\section{Material and Methods}

\section{Study area}

The Leste Maranhense mesoregion (Fig. 1) is composed of 44 municipalities and is located in the eastern portion of the state along the border with Piauí, wherein North refers to the municipality of Araioses, South to Nova Iorque and West to Mirador (IMESC 2010). This study was conducted in four municipalities geographically located in the center of the mesoregion: Aldeias Altas, Caxias, Codó and São João do Sóter (Fig. 1). The climate of the Leste Maranhense mesoregion is of the type "Aw", Tropical with dry winter season (Köppen 1948), with average annual temperatures above $22^{\circ} \mathrm{C}$ and rainfall ranging from $1,200 \mathrm{~mm}$ to 2,500 mm (Aquino \& Santos 2016).

The municipality of Caxias (04.51'32"S, $\left.43^{\circ} 21^{\prime} 22^{\prime \prime} \mathrm{W}\right)$ with an extent of $5,196.769 \mathrm{~km}^{2}$, has transitional vegetation between pre-Amazon Forest and Cerrado, (Caxias 2011; Costa et al. 2017; IBGE 2019). The municipality of Codó ( $04^{\circ} 27^{\prime} 12^{\prime \prime} \mathrm{S}$, $43^{\circ} 53^{\prime} 01$ ' W) with $4,364.50 \mathrm{~km}^{2}$, consists of vegetation ranging from babassu groves, Cerrado s.S. and ombrophilous forests (Amazon Rainforest), and the municipality is within the area of coverage of the Legal Amazon (Codó 2011; IBGE 2019). The municipality of Aldeias Altas (04.37'12's, $43^{\circ} 28^{\prime} 12^{\prime \prime} \mathrm{W}$ ) with $1,942 \mathrm{~km}^{2}$, has Cerrado s.s. and babassu grove vegetation types (Aldeias Altas 2011; Oliveira et al. 2016, 2017; IBGE 2019). The municipality of São João do Sóter $\left(05^{\circ} 06^{\prime} 36^{\prime \prime}\right.$, $43^{\circ} 48^{\prime} 36^{\prime \prime}$ ) with $1,438 \mathrm{~km}^{2}$, has predominantly Cerrado s.s. vegetation (São João do Sóter 2011; Oliveira et al. 2019; IBGE 2019). 
The selected municipalities are inserted in ecotone areas with floristic characteristics of the Amazon Rainforest, Cerrado and Caatinga Biomes. Therefore, they have environmental gradients of rainfall, relief and soil (Maranhão 2011), thus giving them a wide variety of natural environments resulting from the influence of the transitional conditions between the Amazon and the semi-arid Northeast.

\section{Collection and analysis of data}

Field expeditions were carried out monthly between December 2015 and March 2019. The material was pressed and dried, following the usual methodology in taxonomy (Fidalgo \& Bononi 1989). The vouchers were incorporated into the herbarium Aylton Brandão Joly (HABIT), from the State University of Maranhão in Caxias (CESC/UEMA) with duplicates sent to Herbarium do Maranhão (MAR) at the Federal University of Maranhão in São Luís (Campus Dom Delgado) (acronyms according to Thiers, continuously updated).

For each specimen collected, photographic, habitat and phorophyte data (in the case of epiphytes) were recorded. Species identification was performed with the use of specialized literature such as Pabst \& Dungs $(1975,1977)$, Batista et al. (2008), Koch \& Silva (2012), Farias et al. (2016), and Afonso et al. (2016), in addition to the protologues of the species and type vouchers when available online (SpeciesLink 2019; Flora do Brasil 2020; Tropicos 2019).

In addition to the specimens from the collections performed in the study areas, searches were also performed for available vouchers deposited in local herbaria (HABIT, HENAC and BMA) in order to find materials from previous collections in the sampled sites.

Scientific names and geographical distribution of the species are in accordance with the updated databases of Flora do Brasil (2020), World Checklist of Selected Plant Families (Govaerts et al. 2019), Missouri Botanical Garden (Tropicos 2019) and The Plant List (2019).

Classification of vegetation (habitats) is in accordance with IBGE (2012) which names the areas sampled as babassu groves, Cerrado, Gallery Forest, and Urban Perimeter. Regarding occurrence, the species were classified as being 1 .

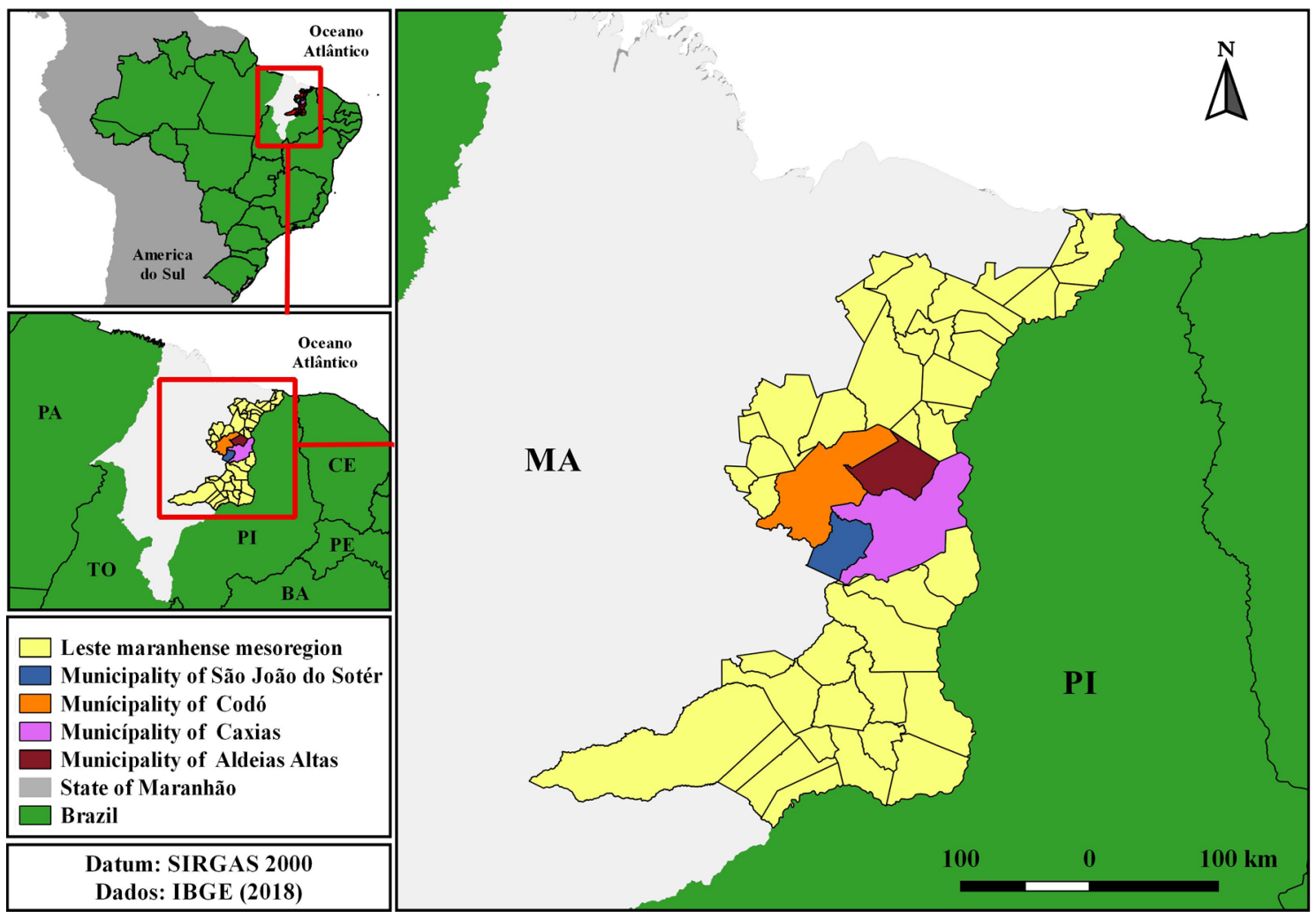

Figure 1 - Location of eastern Maranhão, highlighting the municipalities studied. 
Rare: when they have occurrence restricted to only one population in a municipality; 2. Occasional: when found in more than one municipality, but with only one population known by area; and 3 . Common: when several populations are known in several municipalities.

\section{Results and Discussion}

Seventeen species (Figs. 2;3) were found, distributed in seven genera, with Catasetum (five species) and Habenaria (four species) being the most species rich. Regarding other studies in Cerrado areas, this number is lower than those found by Ferreira et al. (2010) in São Paulo (218 species), Batista et al. (2005) in the Federal District (100 species), Vieira \& Barros (2017) in Minas Gerais (75 species), Hall et al. (2013) in the state of Goiás (28 species) and Rodriguez et al. (2009) in Mato Grosso do Sul (21 species). The lower richness found may be related both to climatic/ pluviometric aspects that characterize the eastern Maranhão as a drier region (transition to the semiarid Northeast), as well as to the smaller total preserved area.

The epiphytic habit is predominant $(47 \%)$ among the species, while many $(41 \%)$ are
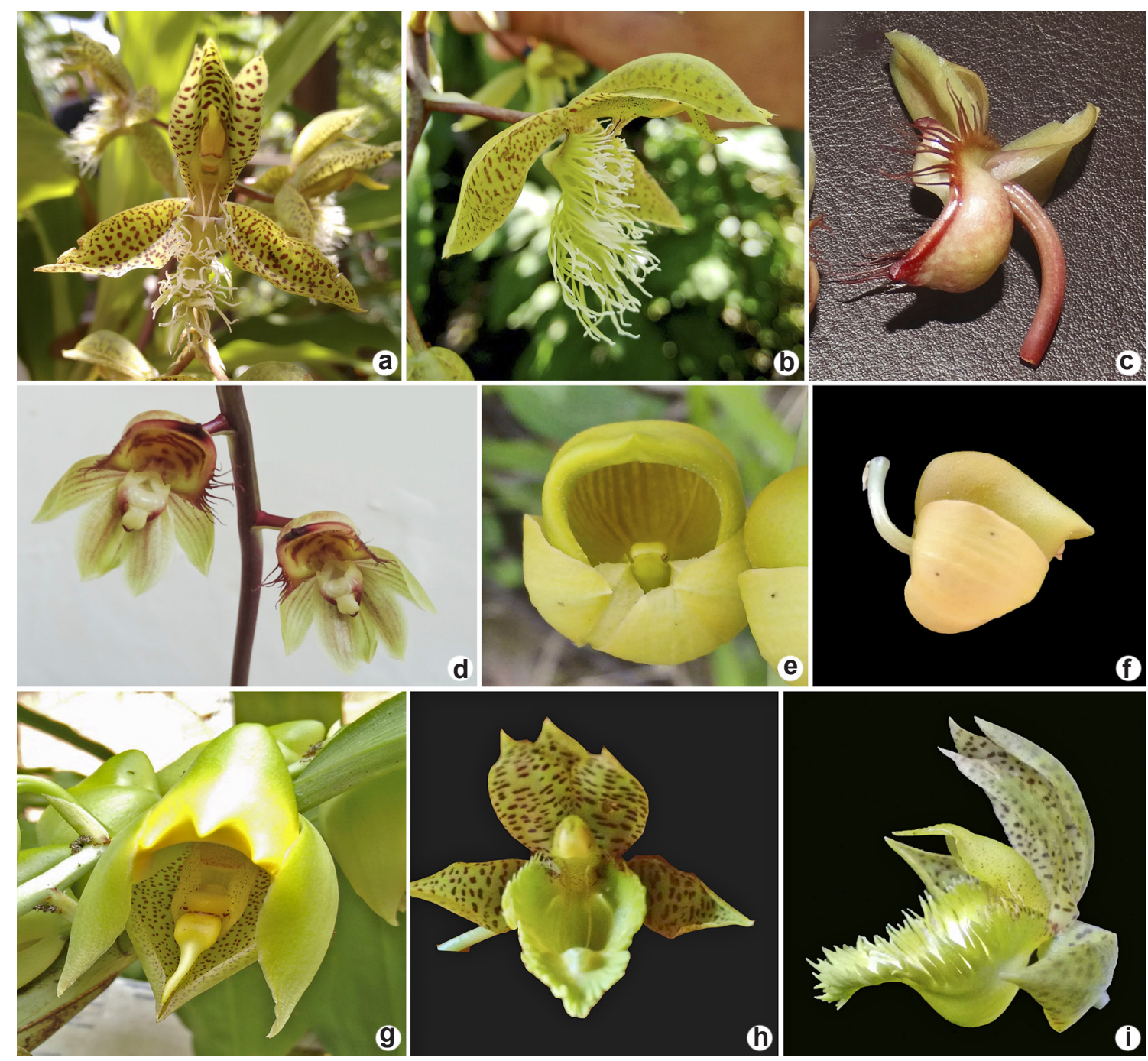

Figure 2 - a-i. Orchidaceae found in the study area - a-b. Catasetum barbatum - a. frontal view; b. lateral view; c-d. Catasetum ciliatum - c. lateral view; d. frontal view; e-f. Catasetum maranhense - e. frontal view; f. lateral view; g. Catasetum macrocarpum - superior view; h-i. Catasetum seccoi - h. frontal view; i. lateral view. (a-b. M.S. Oliveira 04; c-d. A.W.C. Ferreira \& M.S. Oliveira 130; e-f. M.S. Oliveira 159; g. M.S. Oliveira 161; h-i. M.S. de Oliveira 50). 
terrestrial and a few (12\%) are hemiepiphytic; aquatic/palustrine or micro-heterotrophic were not found. The Cerrado s.s. and babassu groves, each supporting $33 \%$ of the species richness, were the vegetational types with the highest number of species found.

The subtribe Catasetinae was the most representative in the area with seven species,
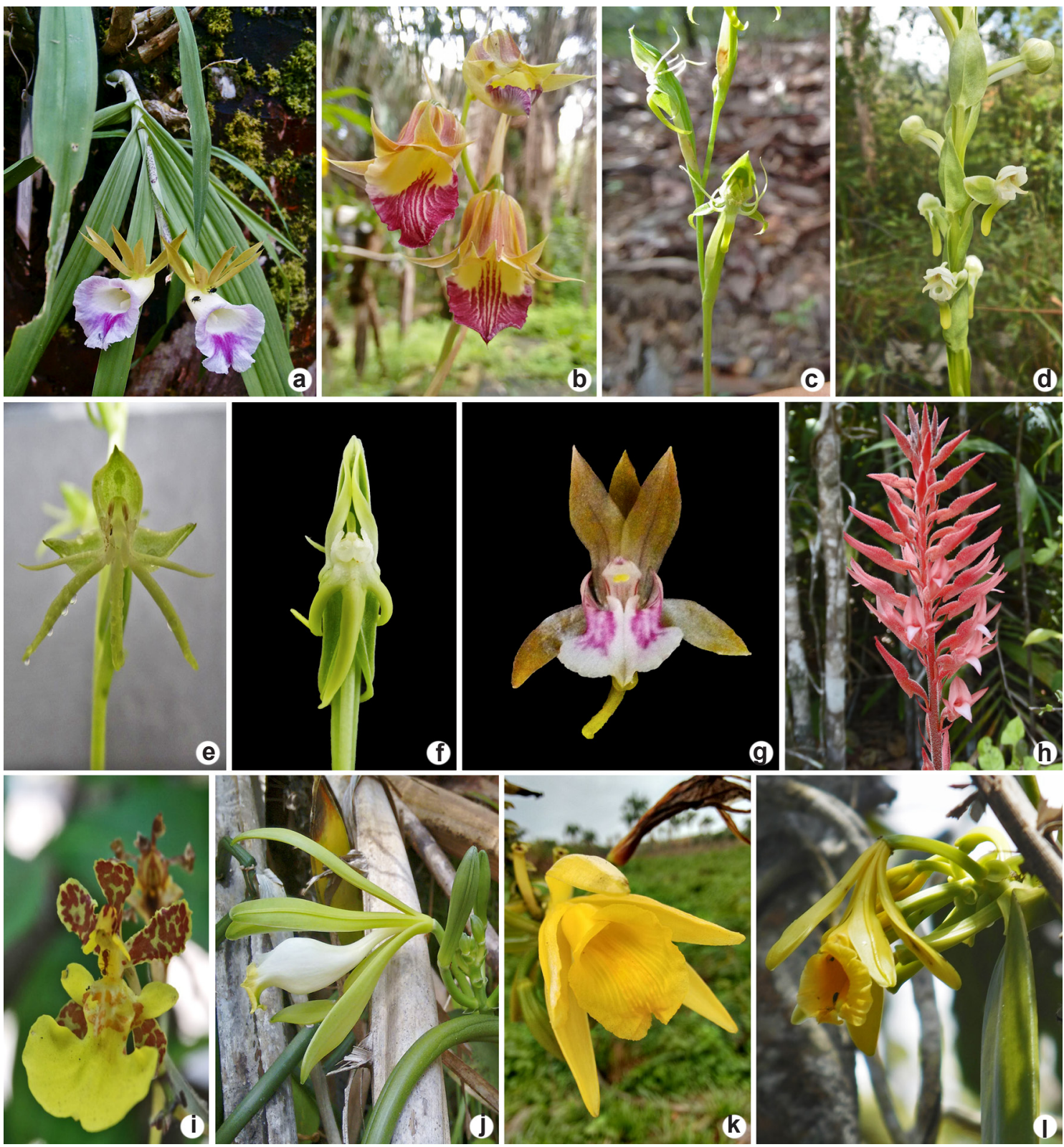

Figure 3 - a-l. Orchidaceae found in the study area - a. Galeandra blanchetii - flower and habit; b. Galeandra montana - flower; c. Habenaria nuda - flower; d. Habenaria obtusa - flower; e. Habenaria schenckii - flower; f. Habenaria trifida - flower; g. Oeceoclades maculata - flower; h. Sacoila lanceolata - flower; i. Trichocentrum cepula - flower; j. Vanilla bahiana - flower; k. Vanilla palmarum - flower; 1. Vanilla pompona. (a. M.S. de Oliveira 12; b. M.S. de Oliveira \& A.W.C. Ferreira 157; c. M.S. de Oliveira 124; d. A.W.C. Ferreira \& M.S. de Oliveira 215; e. A.W.C. Ferreira \& M.S. de Oliveira 153; f. M.S. de Oliveira \& A.W.C. Ferreira 167; g. M.S. de Oliveira 18; h. M.S. de Oliveira 139; i. M.S. de Oliveira 138; j. M.S. de Oliveira 100; k. M.S. de Oliveira 22; 1. M.S. de Oliveira 82). 
among which $C$. seccoi is endemic to the state of Maranhão (BFG 2018). Of the listed species, Catasetum maranhense K.G.Lacerda \& J.B.F.Silva, Catasetum seccoi M.F.F.Silva \& A.T.Oliveira, Galeandra blanchetii E.S.Rand, Galeandra montana Barb.Rodr., Habenaria nuda Lindl and Vanilla bahiana Hoehne, have restricted occurrence in South America; they are, in fact, endemic to Brazil (Govaerts et al. 2019). However, only Catasetum barbatum (Lindl.) Lindl. and Oeceoclades maculata (Lindl.) Lindl. have a conservation status defined as of "Least Concern" (LC) according to IUCN criteria, with the other species still undetermined (RomandMonnier 2013a,b). The species Habenaria schenckii Cogn. is mentioned here for the first time for the flora of Maranhão (BFG 2018; Flora do Brasil 2020).

The species Catasetum maranhense was the most common, being registered in all four municipalities sampled. Catasetum barbatum, $G$. blanchetii, O. maculata, Sacoila lanceolata and $V$. bahiana were occasional and the other species were considered rare.
The municipality of Caxias was the richest with 13 species (76\%), six of which were collected in the Environmental Protection Areas (APAs) existing in the municipality (APA Municipal do Buriti do Meio and APA Municipal do Inhamum). Caxias is the largest municipality sampled, with large preserved native forest fragments and habitats with favorable conditions for the occurrence of Orchidaceae. On the other hand, the municipalities of Aldeias Altas and São João do Sóter presented three species each; in these municipalities the majority of forests are secondary and there is constant fragmentation and loss of habitats due to burning and deforestation (Aldeias Altas 2011; São João do Sóter 2011; Oliveira et al. 2016, 2017; IBGE 2019).

The results point to the little-explored floristic potential of the ecotonal regions of Maranhão. This is best demonstrated by the new record of $H$. schenckii, pointed out here, which joins the recent citations of $V$. bahiana and $V$. pompona (Ferreira et al. 2017) emphasizing the importance of Conservation Units for the maintenance of orchid populations in the east of the state.

\section{Identification key to the species of Orchidaceae in the study area}

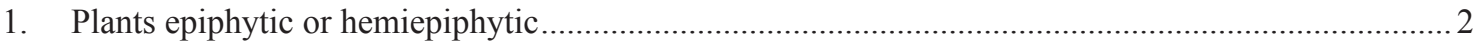

2. Pseudobulb absent.

3. Plants epiphytic; lip without callus

16. Vanilla palmarum

3'. Plants hemiepiphytic; lip with callus 4

4. Leaves oblong, flowers completely yellow 17. Vanilla pompona

4'. Leaves narrow-elliptical, flowers with green sepals and petals and lip pale yellow.......

15. Vanilla bahiana

2'. Pseudobulb present

14. Trichocentrum cepula

5. Leaves 1, apical, cylindrical.....

5'. Leaves 4-8, distributed along the stem, plane

6. Flowers with a spur

6. Galeandra blanchetti

6'. Flowers without a spur.....

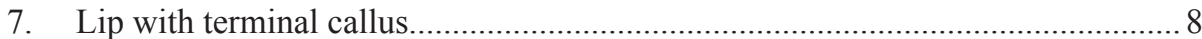

8. Central callus of the lip 3-dentate, margins fimbriate

1. Catasetum barbatum

8'. Central callus of the lip 2-dentate, margins denticulate

5. Catasetum seccoi

7'. Lip without terminal callus 9

9. Margins of the lip ciliate 2. Catasetum ciliatum

9'. Margins of the lip entire 10

10. Petals $\leq 1.9 \mathrm{~cm}$ long, yellow …………….... 3. Catasetum maranhense $10^{\prime}$. Petals $\geq 4.4 \mathrm{~cm}$ long, pale with purple spots

4. Catasetum macrocarpum

1'. Plants terrestrial

11. Pseudobulbs present. 
12. Leaves thick; inflorescences with 11-15 flowers

12. Oeceoclades maculata

12'. Leaves membranaceous; inflorescences with 2-3 flowers 7. Galeandra montana

11'. Pseudobulbs absent. 13

13. Leafless during flowering; sepals and petals reddish or pinkish. 13. Sacoila lanceolata

13'. Leaves present during flowering; sepals and petals greenish or white........ 14

14. Spur $\leq 3 \mathrm{~cm}$ long 15

15. Leaves $2-6$, distributed along the stem 8. Habenaria nuda

15 '. Leaves 2, parallel to the soil level 10. Habenaria schenckii

$14^{\prime}$. Spur $\geq 3.6 \mathrm{~cm}$ long. 16

16. Petals and lip entire or with only lateral appendages 9. Habenaria obtusa

16'. Petals 2-parted; lip 3-parted 11. Habenaria trifida

1. Catasetum barbatum (Lindl.) Lindl., Edwards's Bot. Reg. 30 (Misc.): 38. $1844 . \quad$ Fig. 2a-b

Epiphyte, sympodial. Roots cylindrical, thin. Pseudobulb 9-19.7 cm long, green, fusiform, elongated. Leaves $16.6 \times 10-12 \mathrm{~cm}, 4-8$, flat, distributed along the stem, membranaceous, lanceolate, apex acute, leaves present during flowering. Inflorescence $29.2-61.5 \mathrm{~cm}$ long, lateral, racemose, erect, slightly curved near the apex; floral bracts $1-2 \times 0.4-0.6 \mathrm{~cm}$, linear to lanceolate, apex acute. Flowers $12-18$, resupinate, not spurred; dorsal sepal $2.3-2.5 \times 0.6-0.8 \mathrm{~cm}$, lanceolate, green with brown spots, apex acute; lateral sepals $2.1-2.5 \times 0.8-0.9 \mathrm{~cm}$, lanceolate, green with brown spots, apex acute; petals 2.2-2.5 $\times 0.4-0.6 \mathrm{~cm}$, lanceolate, green with brown spots, apex acute; lip 1.5-1.8 × 0.3-0.6 cm, saccate, green, central callus 3-dentate, terminal callus uni-2-dentate, margin fimbriate, apex aristate; column $1.4-1.7 \mathrm{~cm}$ long, pollinia 2, parallel. Fruit $9.1-10.5 \times 3.2-5.1 \mathrm{~cm}$, fusiform.

Material examined: Caxias, Clube AABB, próxima

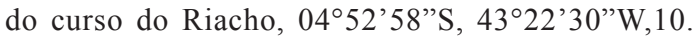
XII.2015, fl., M.S. de Oliveira 03 (MAR); povoado

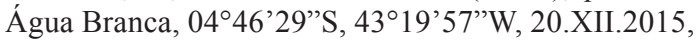
fl., M.S. de Oliveira 04 (MAR); Rod. MA-349, próximo ao IFMA, $04^{\circ} 48^{\prime} 37^{\prime \prime}$ 'S, $43^{\circ} 20^{\prime} 38^{\prime \prime} \mathrm{W}$, 4.III.2016, fl., M.S. de Oliveira 05 (MAR); localidade Shalom, 04 $55^{\circ} 42^{\prime \prime}$, 4314'17'W, 27.XI.2018, fl., M.S. de Oliveira 144, 145 (HABIT); Área de Proteção Ambiental Buriti do Meio, 27.XII.2018, fl., M.S. de Oliveira 149 (MAR); Aldeias

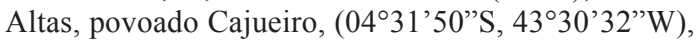
2.XII.2017, fl., M.S. de Oliveira 96 (HABIT).

Catasetum barbatum is occasional in the study area, it blooms between the months of November and March. The species stands out for the great morphological variability of the lip, as already observed by Rocha \& Silva (2001). It was collected in the urban area and in babassu groves, growing on the species Mangifera indica L. (mango tree), Licania tomentosa (Benth.)
Fritsch (oitizeiro) and Attalea speciosa Mart. ex Spreng (babassu palm). It is differentiated from other species of Catasetum in the area by the densely fimbriate lip margin with the presence of an internal 3-dentate callus on the lip.

Widely distributed in South America (Govaerts et al. 2019) and Brazil, it is distributed in the Amazon Rainforest, Cerrado, Caatinga and Pantanal domains, occurring in the states of Amazonas, Pará, Roraima, Tocantins, Maranhão, Piauí, Ceará, Bahia, Alagoas, Paraíba, Pernambuco, Distrito Federal, Goiás, Mato Grosso, Grosso do Sul and Minas Gerais (BFG 2018; Flora do Brasil 2020).

2. Catasetum ciliatum Barb. Rodr., Gen. Sp. Orchid. 1: 130. 1877. Fig. $2 c-d$

Epiphyte, sympodial. Roots cylindrical, thin. Pseudobulb ca. $14-5 \times 17.1 \mathrm{~cm}$, green, fusiform, elongated. Leaves $11.8-29 \times 5-11 \mathrm{~cm}, 4-6$, flat, distributed along the stem, membranaceous, lanceolate, apex acute, leaves present during flowering. Inflorescence 18.9-24.1 cm long, lateral, racemose, erect, slightly curved near the apex; floral bracts ca. $1.1 \times 0.3-0.4 \mathrm{~cm}$, lanceolate, apex acute. Flowers 8-13, not resupinate, not spurred; dorsal sepal 1.5-1.8 × 0.6-0.8 cm, elliptical, greenish, apex acute; lateral sepals $1.6-2 \times 0.6-0.8 \mathrm{~cm}$, slightly falcate, apex acute; petals $1.8-2.2 \times 0.6-0.8 \mathrm{~cm}$, oval, greenish, apex acute; lip 1.1-1.4 × 0.6-1.0 cm, cucullate, greenish-red, callus absent, margin ciliate, apex curved; column $0.5-1 \mathrm{~cm}$ long, pollinia 2, parallel. Fruit not observed.

Material examined: Codó, Rio Saco, margem esquerda da rodovia MA-026 sentido Codó, 04³1'28”'S, 4356'23”'W, 27.VII.2018, fl., M.S. de Oliveira \& A.W.C. Ferreira 130 (MAR).

Catasetum ciliatum is rare in the study area, with few individuals observed, blooms in 
the month of July. It was collected on M. indica. The species differs from the other species of Catasetum in the study area by the lip without callus and with a ciliate margin.

Widely distributed in South America (Govaerts et al. 2019) and Brazil, it is distributed only in the Amazon Rainforest domain, with confirmed occurrence in the states of Amazonas, Amapá, Pará, Rondônia, Roraima and Maranhão (BFG 2018; Flora do Brasil 2020).

3. Catasetum maranhense K.G. Lacerda \& J.B.F. Silva, Bradea 8(13): 69. 1998.

Fig. 2e-f

Epiphyte, sympodial. Roots cylindrical, thin. Pseudobulb 7.1-37.2 cm long, green, fusiform, elongated. Leaves $25.0-28.5 \times 4-5 \mathrm{~cm}, 4-6$, flat, distributed along the stem, membranaceous, lanceolate, apex acute, leaves present during flowering. Inflorescence 11-23 cm long, lateral, racemose, erect, slightly curved near the apex; floral bracts $0.7-0.9 \times 0.3-0.4 \mathrm{~cm}$, lanceolate, apex acute. Flowers 6-8, resupinate, not spurred; dorsal sepal 1.5-1.9 × 0.6-0.9 cm, elliptical, yellow, apex acute; lateral sepals 1.8-1.9 $\times$ $0.7-0.8 \mathrm{~cm}$, elliptical to slightly falcate, yellow, apex acute; petals $1.5-1.9 \times 0.7-0.8 \mathrm{~cm}$, ovate to elliptical, yellow, apex acute; lip 1.3-1.5 × 1-1.2 $\mathrm{cm}$, elliptical, yellow, callus absent, margin entire, apex curved; column $0.8-1 \mathrm{~cm}$ long, pollinia 2, parallel. Fruit not observed.

Material examined: Codó, Fazenda Santa Rita, 0444'58"S, 44¹0'33"W, 15.VII.2016, fl., M.S. de Oliveira 11 (MAR); Fazenda Santa Rita, 25.III.2019, fl., M.S. de Oliveira 159 (MAR). Aldeias Altas, povoado

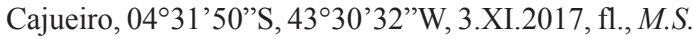
de Oliveira 97 (HABIT). São João do Sóter, Localidade Olho D'agua do Alfredo, $05^{\circ} 11^{\prime} 38^{\prime \prime} \mathrm{S}, 43^{\circ} 48^{\prime} 35^{\prime} \mathrm{W}$, 20.IV.2019, fl., M.S. de Oliveira 162 (HABIT). Caxias,

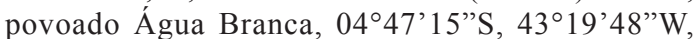
22.IV.2019, fl., M.S. de Oliveira 166 (HABIT).

Catasetum maranhense it is common in the study area, with several populations found exclusively on $A$. speciosa in all municipalities sampled. It blooms between the months of November and April. It differs from the other species of Catasetum listed here by its lip without calluses and with an entire margin, being similar to C. macrocarpum, from which it can be distinguished by petals $<1.9 \mathrm{~cm}$ long (vs. $>4.4$ cm long).

Endemic to Brazil (Govaerts et al. 2019), it is distributed in the Amazon, Cerrado and Caatinga domains, occurring in the states of Pará, Maranhão and Piauí (BFG 2018; Flora do Brasil 2020).
4. Catasetum macrocarpum Rich. ex Kunth., Syn. P1. 1: 331.1822.

Fig. $2 \mathrm{~g}$

Epiphyte, sympodial. Roots cylindrical, thin. Pseudobulb 10-15.3 cm long, green, fusiform, elongated. Leaves $16-23.5 \times 3.1-7.2 \mathrm{~cm}, 4-6$, flat, distributed along the stem, membranaceous, lanceolate, apex acute, leaves present during flowering. Inflorescence 11-14.9 cm long, lateral, racemose, erect; floral bracts $1-1.3 \times$ $0.3-0.5 \mathrm{~cm}$, lanceolate, apex acute. Flowers 4-6, not resupinate, not spurred; dorsal sepal 4.3-4.5 $\times 1.6-2.1 \mathrm{~cm}$, elliptical, greenish, apex acute; lateral sepals $4.5-5.0 \times 2.1-2.5 \mathrm{~cm}$, elliptical to slightly falcate, greenish, apex acute; petals $4.4-4.7 \times 2.2-2.7 \mathrm{~cm}$, elliptical, greenish with brown spots, apex acute; lip 3.3-3.5 × 1-1.7 cm, stiff, greenish-yellow, callus absent, margin entire, apex aristate; column $3.5-4.2 \mathrm{~cm}$ long, pollinia 2, parallel or curved in relation to each other. Fruit not observed.

Material examined: município de Codó, Fazenda Santa

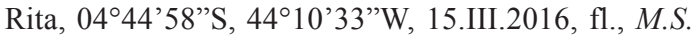
de Oliveira 06 (MAR); Fazenda Santa Rita, 11.V.2016, fl., M.S. de Oliveira 07 (HABIT); 15.VI.2016, fl., M.S. de Oliveira 11 (MAR); Rod. MA-316, margem direta

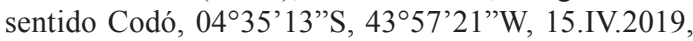
fl., M.S. de Oliveira 161 (HABIT).

Catasetum macrocarpum is rare in the study area, it blooms between the months of March and June. It was collected in areas of babassu groves, growing exclusively on $A$. speciosa. It differs easily from the other species of Catasetum in the study area by the larger flowers (petals $>4.4 \mathrm{~cm}$ long) and by the lip without calluses and with entire margin.

Widely distributed in South America (Govaerts et al. 2019) and Brazil, it is distributed in the domains of the Amazon Rainforest, Cerrado and Atlantic Forest, occurring in the states of Acre, Amazonas, Amapá, Pará, Roraima, Tocantins, Alagoas, Bahia, Ceará, Maranhão, Paraíba, Pernambuco, Rio Grande do Norte, Goiás, Mato Grosso, Espírito Santo, Minas Gerais, Rio de Janeiro, São Paulo (BFG 2018; Flora do Brasil 2020).

5. Catasetum seccoi M.F.F. Silva \& A.T. Oliveira, Bol. Mus. Paraense Emilio Goeldi, Bot., 15(2): 107. 1999.

Fig. 2h-i

Epiphyte, sympodial. Roots cylindrical, thin. Pseudobulb 15-25.6 cm long, green, fusiform, elongated. Leaves $15-43 \times 5-11 \mathrm{~cm}, 4-6$, flat, distributed along the stem, membranaceous, lanceolate, apex acute, leaves present during flowering. Inflorescence 19.5-48.2 cm long, 
lateral, racemose, erect, slightly curved near the apex; floral bracts $0.9-1.2 \times 0.3-0.4 \mathrm{~cm}$, oval to lanceolate, apex acute. Flowers 10-19, resupinate, not spurred; dorsal sepal 2-2.4 × $0.8-1 \mathrm{~cm}$, lanceolate, green with brown spots, apex acute; lateral sepals $2.1-2.4 \times 0.9-1.1 \mathrm{~cm}$, lanceolate, green with brown spots, apex acute; petals 1.9-2.4 $\times 0.8-1.1 \mathrm{~cm}$, lanceolate, green with brown spots, apex acute; lip 1-1.3 × $0.3-0.5 \mathrm{~cm}$, saccate, green, central callus 2 -dentate, terminal callus triangular, margin denticulate, apex aristate; column 1-1.5 long, pollinia 2, parallel. Fruit not observed.

Material examined: São João do Sóter, Fazenda Boa Vista, 05¹1'32"S, 4344'51'W, 10.IV.2017, fl., M.S. de Oliveira 50 (MAR); Fazenda Boa Vista, 22.II.2018, fl., M.S. de Oliveira 110 (HABIT); Fazenda Boa Vista, 23.II.2018, fl., M.S. de Oliveira 111(HABIT).

Catasetum seccoi is rare in the study area, it blooms between the months of February and April. It was collected in areas of babassu groves, growing exclusively on $A$. speciosa. It differs from the other species of Catasetum in the study area by the denticulate lip margin and the presence of an internal, 2-dentate callus.

Endemic to Brazil (Govaerts et al. 2019), it is registered so far only for the Amazon Rainforest Domain, in the state of Maranhão (BFG 2018; Flora do Brasil 2020). The type specimen was collected in the municipality of Tuntum in a swampy area (Silva \& Oliveira 1999) in a transition area between the Amazon and Cerrado. The collection in the municipality of São João do Sóter represents the first record for a Cerrado area.

6. Galeandra blanchetii E.S. Rand. Orchids 283. 1876.

Fig. 3a

Epiphyte, sympodial. Roots cylindrical, thin. Pseudobulb 4.5-14.5 cm long, green, fusiform, elongated. Leaves $20.1-25.2 \times 1.3-1.5 \mathrm{~cm}, 6-7$, flat, distributed along the stem, membranaceous, linear to lanceolate, apex acute, leaves present during flowering. Inflorescence $3.5-11.3 \mathrm{~cm}$ long, terminal, racemose, erect; floral bracts $0.3-0.6$ cm long, lanceolate, apex acute. Flowers 4-7, resupinate, spurred, spur 1.6-1.9 cm long; dorsal sepal 1.9-2.3 $\times 0.3-0.5 \mathrm{~cm}$, lanceolate, orange, apex acute; lateral sepals 2-2.5 ×0.3-0.6 cm, lanceolate, brownish, falcate, apex acute; petals $2-2.4 \times 0.4-0.5$ $\mathrm{cm}$, lanceolate, brownish, apex acute; lip 3.3-4.1 $\times$ $4.2-4.6 \mathrm{~cm}$, rhomboid, white with purple spot at the apex, callus absent, margin wavy, apex emarginate; column 1.1-1.5 cm long, pollinia 2, parallel. Fruit $4.1-5.2 \mathrm{~cm}$ long, fusiform.
Material examined: Caxias, povoado Aroeira, 0447'16”S, 43¹9'14”W, 19.IX.2016, fl., M.S. de Oliveira 12 (HABIT); povoado Água Branca, 0446'59'S, 4319'14"W, 20.IX.2016, fl., M.S. de Oliveira 13 (HABIT). Aldeias Altas, povoado Cajueiro, 04³1'50'S, 4330'32”'W, 2.XI.2017, fl., M.S. de Oliveira 95 (MAR).

Galeandra blanchetii is occasional in the study area, it blooms between the months of September and November. It was collected in babassu groves, growing exclusively on $A$. speciosa. It is easily distinguished from the other species of Galeandra in the area by the epiphytic habit and pseudobulb shape (fusiform vs. ovoid).

Endemic to Brazil (Govaerts et al. 2019), it is distributed in the Amazon Rainforest, Cerrado and Caatinga domains, occurring in the states of Pará, Rondônia, Tocantins, Maranhão, Piauí, Mato Grosso, Goiás and Minas Gerais (BFG 2018; Flora do Brasil 2020).

7. Galeandra montana Barb.Rodr. Gen. Sp. Orchid. 2: 175.1882.

Fig. 3b

Terrestrial, sympodial. Roots cylindrical, slender. Pseudobulb 3.1-5.1 × 1.3-2.8 cm, light green, ovoid. Leaves $13-71 \times 1.5-1.8 \mathrm{~cm}, 5-6$, flat, distributed along the stem, membranaceous, lanceolate, apex acute, leaves present during flowering. Inflorescence 50-71 cm long, terminal, racemose, erect; floral bracts $1.5-3.5 \times 0.3 \mathrm{~cm}$, lanceolate, apex acute. Flowers 2-3, resupinate, spurred, spur 1.5-1.7 cm long; dorsal sepal 2.5-2.9 $\times 0.4-0.6 \mathrm{~cm}$, lanceolate, reddish brown, apex acute; lateral sepals 3-3.3 ×0.4-0.5 cm, lanceolate, falcate, reddish brown, apex acute; petals 2.5-2.8 $\times 0.5-0.7 \mathrm{~cm}$, lanceolate, reddish brown, apex acute; lip 1.3-1.6 × 2.9-3.1 cm, rhomboid, callus absent, margin wavy, apex obtuse; column 1.2-1.6 $\mathrm{cm}$ long, pollinia 2, parallel. Fruit 3-3.6 × 1.1-1.5 $\mathrm{cm}$, capsular.

Material examined: Caxias, Rod. MA-316, margem direita sentido Caxias, 0444'35"S, 4343'60"W, 9.III.2019, fl., M.S. de Oliveira \& A.W.C. Ferreira 157, 158 (HABIT); Rod. MA-316, margem direita sentido Caxias, 21.IV.2019, fl and fr., M.S. de Oliveira \& A.W.C. Ferreira 163 (MAR).

Galeandra montana is rare in the study area, it blooms from March to April. It was collected in the Cerrado at the end of the rainy season. The only other terrestrial species in the area with pseudobulbs and spurred flowers is Oeceoclades maculata, from which $G$. montana is easily distinguished by its membranous leaves, vs. coriaceous in O. maculata.

Endemic to Brazil (Govaerts et al. 2019), it is distributed in the Amazon Rainforest, Cerrado and 
Atlantic Forest domains, occurring in the states of Amazonas, Pará, Tocantins, Bahia, Maranhão, Rio Grande do Norte, Sergipe, Distrito Federal, Goiás, Mato Grosso do Sul, Mato Grosso, Minas Gerais and São Paulo (BFG 2018; Flora do Brasil 2020).

8. Habenaria nuda Lindl., Gen. Sp. Orchid. Pl. 312. 1835.

Fig. 3c

Terrestrial, sympodial. Roots cylindrical, thin. Stem 41-52.3 cm long, green, cylindrical. Leaves $10.3-14.2 \times 0.3-0.5 \mathrm{~cm}, 4-5$, flat, distributed along the stem, membranaceous, linear to lanceolate, apex acute, leaves present during flowering. Inflorescence 14.1-16.2 cm long, terminal, racemose, sparse, erect; floral bracts $1.5-3.1 \times 0.4-0.5 \mathrm{~cm}$, lanceolate, apex acuminate. Flowers 4-5, resupinate, spurred, the spur 1.4-1.6 cm long; dorsal sepal $0.5-0.6 \times 0.4-0.5 \mathrm{~cm}$, ovate, green, apex apiculate; lateral sepals $0.7-1.2 \times$ $0.2-0.3 \mathrm{~cm}$, lanceolate, falcate, apex apiculate; petals $0.6-0.8 \times 0.3-0.5 \mathrm{~cm}$, lanceolate, 2-parted, upper segment $0.6-0.8 \times 0.2-0.3 \mathrm{~cm}$, lanceolate, falcate, apex acute, lower segment $1.1-1.2 \mathrm{~cm}$ long, linear, apex acute; lip 1.1-1.3 × 0.3-0.6 $\mathrm{cm}, 3$-parted, callus absent, margin entire, middle segment $0.5-0.8 \times 0.2-0.3 \mathrm{~cm}$, linear, apex acute, lateral segments $0.6-0.8 \times 0.2 \mathrm{~cm}$, linear-falcate, apex acute; column $0.3 \mathrm{~cm}$ long, pollinia 2, parallel. Fruit not observed.

Material examined: Caxias, Área de Proteção Ambiental Municipal do Inhamum, $04^{\circ} 54^{\prime} 16,7^{\prime \prime} \mathrm{S}, 43^{\circ} 25^{\prime} 33^{\prime \prime} \mathrm{W}$, 5.V.2018, fl., M.S. de Oliveira 124 (HABIT).

Habenaria nuda is rare in the study area, blooming in the Cerrado in May, at the end of the rainy season. Among the other species of the genus, $H$. trifida would be the closest, due to the leaves distributed along the stem, 2-parted petals and 3-parted lip. These species can be easily differentiated by the length of the spur $(\leq 1.6 \mathrm{~cm}$ in H. nuda vs. $>6 \mathrm{~cm}$ in H. trifida).

Endemic to Brazil (Govaerts et al. 2019), it is distributed in the Amazon Rainforest, Cerrado, Caatinga, and Atlantic Forest domains, occurring in the states of Amazonas, Pará, Tocantins, Bahia, Maranhão, Distrito Federal, Goiás, Mato Grosso do Sul, Mato Grosso, Minas Gerais, Rio de Janeiro, São Paulo, Paraná and Santa Catarina (BFG 2018; Flora do Brasil 2020).

9. Habenaria obtusa Lindl., Gen. Sp. Orchid. Pl.: 315. 1835.

Fig. 3d

Terrestrial, sympodial. Roots cylindrical, slender. Stem 30.1-65.2 cm long, green, cylindrical.
Leaves 9.2-12.5 × 2-3.5 cm, 5-6, flat, distributed along the stem, membranaceous, lanceolate, apex acute, leaves present during flowering. Inflorescence $15.1-30.5 \mathrm{~cm}$ long, terminal, racemose, erect; floral bracts 2.1-2.9 × 0.6-1.1 $\mathrm{cm}$, ovate, apex acute. Flowers 9-15, resupinate, spurred, spur 3.6-4.2 cm long; dorsal sepal 0.6-0.9 $\times 0.7-0.8 \mathrm{~cm}$, ovate, green, apex acute; lateral sepals $0.8-0.9 \times 4.1-4.9 \mathrm{~cm}$, ovate, green, apex acute; petals $0.7-0.9 \times 1.5-2.5 \mathrm{~cm}$, elliptical, green, apex acute; lip 1.0-1.2 × 1.6-1.9 cm, linear-oblong, white, callus absent, margin entire, apex rounded; column $0.5-0.9 \mathrm{~cm}$ long, pollinia 2, parallel. Fruit not observed.

Material examined: Caxias, Balneário Veneza, próximo da nascente, $04^{\circ} 54^{\prime} 55,7^{\prime}$ 'S, 432 $21^{\prime} 23,7^{\prime}$ 'W, 30.III.2015, fl., A.W.C. Ferreira \& M.S. de Oliveira 215 (MAR).

Habenaria obtusa is rare in the study area, it blooms in the month of March, during the rainy season. The species was collected in the Cerrado in sandy soil. It is distinguished from other species of Habenaria by its entire petals and lip, sometimes with lateral appendages.

Widely distributed in South America (Govaerts et al. 2019) and Brazil, where it is distributed in the domains of the Amazon Rainforest, Cerrado, Caatinga, occurring in the states of Pará, Rondônia, Roraima, Tocantins, Maranhão, Piauí, Alagoas, Bahia, Paraíba, Pernambuco, Sergipe, Distrito Federal, Goiás, Mato Grosso, Mato Grosso do Sul, Minas Gerais, São Paulo and Paraná (BFG 2018; Flora do Brasil 2020).

10. Habenaria schenckii Cogn., Fl. bras. 3(4): 61. 1893.

Fig. 3e

Terrestrial, sympodial. Roots cylindrical, thin. Stem 15-25.8 cm long, green, cylindrical. Leaves $5.6-7.3 \times 2.3-3.8 \mathrm{~cm}, 2$, flat, parallel to each other, membranaceous, orbicular, apex acute, leaves present during flowering. Inflorescence $15.1-23.5 \mathrm{~cm}$ long, terminal, racemose, erect; floral bracts $1.6-1.8 \times 0.5-0.6 \mathrm{~cm}$, ovate to lanceolate, apex acute. Flowers 5-8, resupinate, spurred, spur $2.7-3.0 \mathrm{~cm}$ long; dorsal sepal $0.6-0.7 \times 0.4-0.5$ $\mathrm{cm}$, ovate to lanceolate, green, apex acute; lateral sepals $0.7-0.8 \times 0.3-0.5 \mathrm{~cm}$, obovate, green, apex acute; petals $0.6-0.7 \times 0.1-0.3 \mathrm{~cm}, 2$-parted, upper segment $0.6-0.7 \times 0.2-0.3 \mathrm{~cm}$, triangular to lanceolate, falcate, apex acute, lower segment $0.9-1.0 \mathrm{~cm}$ long, linear to lanceolate, apex acute; lip 1.1-1.4 × 0.2-0.4 cm, 3-parted, green, callus absent, margin entire, middle segment 0.6-0.9 $\times$ $0.1-0.3 \mathrm{~cm}$, linear, apex acute, lateral segments 
linear, apex acute; column $0.3 \mathrm{~cm}$ long, pollinia 2, parallel. Fruit not observed.

Material examined: Caxias, estrada de terra nas margens da rodovia BR-316, à esquerda do sentido CaxiasCodó, cerca de 300 metros da rodovia, em Cerrado com transição para Mata de Galeria. 0444'36"S, 4343'23'W, 29.III.2019, fl., A.W.C. Ferreira \& M.S. de Oliveira 153, 154 (MAR), 155 (HABIT).

Habenaria schenckii is rare in the study area, it blooms in March, during the rainy season. A small population was found, with about 50 individuals growing very close together and at various phenological ages, from juvenile to fertile plants (only three blooming individuals), in a typical fragment of Cerrado in transition to gallery forest. It is easily distinguished from other species of Habenaria in the area because it has only two leaves parallel at the level the soil.

It occurs in northern Argentina (Tucumán) and is widely distributed in Brazil (Govaerts et al. 2019), found in the domains of the Amazon Rainforest, Cerrado and Caatinga, and until now cited for the states of Pará, Bahia, Paraíba, Pernambuco, Piauí, Rio Grande do Norte, Sergipe, Goiás, Mato Grosso, Minas Gerais (BFG 2018; Flora do Brasil 2020). This is a new record for Flora do Maranhão (BFG 2018). Habenaria depressifolia Hoehne is very similar (Batista et al. 2008) and is already cited for the state, however the length of the leaves and floral parts allowed us to be sure of the identity of the material collected in Caxias.

\section{Habenaria trifida Kunth., Nov. Gen. Sp., 1:} 330. 1815.

Fig. $3 f$

Terrestrial, sympodial. Roots cylindrical, thin. Stem 21.8-28 cm long, green, cylindrical. Leaves 2.3-4.2 × 1.3-1.5 cm, 4-6, flat, distributed along the stem, membranaceous, linear to lanceolate, apex acuminate, leaves present during flowering. Inflorescence 5-8 cm long, terminal, racemose, erect; floral bracts $1.1-1.4 \times 0.4-0.5 \mathrm{~cm}$, lanceolate, apex acuminate. Flowers 4-8, resupinate, spurred, spur 6.1-7.2 cm long; dorsal sepal 0.6-0.9 × 0.5$0.6 \mathrm{~cm}$, ovate, greenish, apex acute; lateral sepals 0.9-1.1 × 0.3-0.5 cm, ovate, greenish, apex acute; petals 2-parted, upper segment $0.8-1.1 \times 0.2-0.3$ $\mathrm{cm}$, oblong, greenish, apex acute, lower segment $0.8-1.0 \times 0.2-0.5 \mathrm{~cm}$, oblong, greenish, apex acute; labellum 3-parted, greenish, callus absent, margin entire, middle segment ca. $1.0-1.3 \times 0.2 \mathrm{~cm}$, linear, lateral segments ca. $1.1-1.4 \times 0.2 \mathrm{~cm}$, linear, apex acute; column ca. $0.4 \mathrm{~cm}$ long, pollinia 2, parallel. Fruit 5-7 cm long, fusiform.
Material examined: Codó, margem direita da Rod. MA316, área de brejo, 0441'03"S, 4348'12"W, 23.IV.2019, fl., M.S. de Oliveira \& A.W.C. Ferreira 167, 168 (MAR), 169 (HABIT).

Habenaria trifida in rare in the study area, it blooms in the month of April, at the end of the rainy season. It was collected in a swampy area in a Cerrado-type vegetation fragment. It differs from the other species of Habenaria sampled in the area by the elongated spur, more than $6 \mathrm{~cm}$ long.

It occurs from Mexico to South America (Govaerts et al. 2019), and in Brazil, is distributed in the domains of the Amazon Rainforest, Cerrado, Caatinga and Atlantic Forest, occurring in the states of Acre, Amazonas, Amapá, Pará, Roraima, Tocantins, Alagoas, Bahia, Ceará, Maranhão, Paraíba, Pernambuco, Piauí, Sergipe, Distrito Federal, Goiás, Mato Grosso, Espírito Santo, Minas Gerais, Rio de Janeiro, São Paulo (BFG 2018; Flora do Brasil 2020).

12. Oeceoclades maculata (Lindl.) Lindl., Gen. Sp. Orchid. P1. 237. $1833 . \quad$ Fig. 3g

Terrestrial, sympodial. Roots cylindrical, thin. Pseudobulb 2.0-3.2 cm long, green, ovoid. Leaves $16.1-23.0 \times 3.6-5.2 \mathrm{~cm}, 1$, apical, flat, thick, elliptical, apex acute. Inflorescence $27.2-43.4 \mathrm{~cm}$ long, lateral, racemose, erect; floral bracts 0.6-0.9 $\times 0.1-0.3 \mathrm{~cm}$, lanceolate, apex acute, leaves present during flowering. Flowers 11-15, resupinate, spurred, spur 0.4-0.6 cm long; dorsal sepal 0.7-0.9 $\times 0.2-0.3 \mathrm{~cm}$, oblanceolate, brownish, apex acute; lateral sepals $0.8-0.9 \times 0.4-0.5 \mathrm{~cm}$, oblanceolate, falcate, brownish, apex acute; petals $0.6-0.8 \times$ 0.4-0.5 cm, oblanceolate, brownish, apex acute; lip 3-lobed, middle lobe $0.3-0.4 \times 0.4-0.6 \mathrm{~cm}$, lanceolate; white with purple spots, lateral lobes $0.3-0.5 \times 0.4-0.6 \mathrm{~cm}$, lanceolate, callus absent, margin entire, apex emarginate; column 0.3-0.5 $\mathrm{cm}$ long, pollinia 2, parallel. Fruit $6-8 \mathrm{~cm}$ long, fusiform.

Material examined: Caxias, Rua do Cajueiro, próximo do curso do riacho, 21.X.2016, fl., M.S. de Oliveira 18,19,20 (HABIT); Área de Proteção Ambiental Municipal do Inhamum, 0454'15"S, 4325'32"W, 14.X.2018, fr., M.S. de Oliveira 140,141 (MAR).

Oeceoclades maculata in occasional in the study area, it blooms in the month of October. It was collected on sandy soil in shaded areas of gallery forest vegetation. It differs from other species of orchids in the area in that it is the only terrestrial species with thick leaves and flowers with sepals and morrons petals with white lip with purple spots. 
It occurs from tropical Africa to the Americas (Govaerts et al. 2019) and in Brazil, it is distributed in the Amazon Rainforest, Cerrado, Caatinga and Atlantic Forest domains, occurring in the five regions of the country and in almost all states (BFG 2018; Flora do Brasil 2020).

13. Sacoila lanceolata (Aubl.) Garay. Bot. Mus. Leafl. 28(4): 352. 1980 [1982].

Fig. 3h

Terrestrial, sympodial. Roots cylindrical, fleshy. Stem $0.3-1.5 \mathrm{~cm}$ long, yellowish, cylindrical. Leaves 16.1-35.2 × 2.6-4.2 cm, 3-4, flat, forming a rosette, membranaceous, lanceolate, apex acute, leafless during flowering. Inflorescence $22-38.1 \mathrm{~cm}$ long, terminal, racemose, erect; floral bracts 0.9-1.0 $\times 1.2-1.8 \mathrm{~cm}$, lanceolate, apex acute. Flowers 19 28 , resupinate, mentum $0.4 \mathrm{~cm}$ long; dorsal sepal 1.4-1.8 × 0.4-0.5 cm, lanceolate, reddish, apex acute; lateral sepals $2.1-2.3 \times 0.3-0.4 \mathrm{~cm}$, elliptical to lanceolate, reddish, apex acute; petals 1.5-2.2 $\times$ $0.3-0.5 \mathrm{~cm}$, lanceolate, reddish, apex acuminate; lip 3-lobed, reddish, callus absent, margin entire, middle lobe $1.8-2.4 \times 0.4-0.6 \mathrm{~cm}$, lanceolate, apex acute, lateral lobes $0.3-0.4 \times 0.4-0.5 \mathrm{~cm}$, lanceolate, falcate, apex acute; column $0.8-1.3 \mathrm{~cm}$ long, pollinia 2, parallel. Fruit not observed.

Material examined: Codó, Fazenda Santa Rita, 0443'21'S, 4409'38"W, 11.XI.2015, fl., M.S. de Oliveira 02 (HABIT); Fazenda Santa Rita, 11.X.2018, fl., M.S. de Oliveira 139 (HABIT). Caxias, Área de Proteção Ambiental Municipal do Inhamum, 0453'82"S, 4326'13"W, 11.XI.2018, fl., M.S. de Oliveira 142 (MAR).

Sacoila lanceolata is occasional in the area, it has leaves visible only during the rainy season and flowers while leafless between October and November, during the dry season. It was collected in the Cerrado on sandy soil. It is the only species of orchid in the study area that has a mentum, and also the only species that is leafless during flowering.

Widely distributed in the Neotropical region (Govaerts et al. 2019), and in Brazil, it is distributed in the Amazon Rainforest, Cerrado, Caatinga and Atlantic Forest domains, occurring in almost all the states of the country (BFG 2018; Flora do Brasil 2020).

14. Trichocentrum cepula (Hoffmanns.) J.M.H. Shaw, Orchid Rev. Suppl. 120(1297): 16. 2012.

Fig. 3i

Epiphyte, sympodial. Roots cylindrical, thin. Pseudobulb 1.0-1.2 cm long, green, ovoid. Leaves 9.7-25 cm long, 1, apical, thick, cylindrical, apex acute, leaves present during flowering. Inflorescence 15-26 cm long, lateral, racemose or paniculate, erect or pendulous; floral bracts $0.3-0.5 \mathrm{~cm}$ long, lanceolate, apex acute. Flowers 4-6, non-resupinate; dorsal sepal ca. $0.6 \times 0.4$ $\mathrm{cm}$, obovate, yellow with red spots, apex obtuse; lateral sepals ca. $0.6-0.7 \times 0.4 \mathrm{~cm}$, obovate, yellow with red spots, apex obtuse; petals ca. $0.6 \times 0.4$ $\mathrm{cm}$, obovate, yellow with red spots, apex obtuse; lip ca. 1.0-1.2 × $0.9 \mathrm{~cm}, 3$-lobed, yellow, callus absent, margin entire, apex emarginate, middle lobe $1.0-1.1 \times 1.1-1.4 \mathrm{~cm}$, obovate, apex obtuse, lateral lobes $0.6-0.8 \times 0.5-0.6 \mathrm{~cm}$, obovate, apex obtuse; column ca. $0.5 \times 0.2 \mathrm{~cm}$, pollinia 2 , parallel. Fruit $3.5 \mathrm{~cm}$ long, fusiform, elongate.

Material examined: Caxias, Bairro Pirajá, 0452'61'S, 4323'34'W, 19.X.2016, fl. and fr., M.S. de Oliveira 15, 16 (HABIT); bairro Pirajá, 19.X.2016, fl., M.S. de Oliveira 17 (MAR); bairro Ponte, 0452'42”S, $43^{\circ} 22^{\prime} 44^{\prime \prime} \mathrm{W}, 30 . \mathrm{IX} .2018$, fr., M.S. de Oliveira 138 (MAR).

Trichocentrum cepula in rare in the study area, it blooms between the months of September and October. It was collected exclusively in the urban area, growing on the species Anadenanthera colubrina var. cebil (Griseb.) Altschul (angicopreto) and Mangifera indica. It can be distinguished from other species of orchid in the area by having only one cylindrical leaf at the apex of each pseudobulb.

Endemic to South America (Govaerts et al. 2019), in Brazil, it is distributed in the Cerrado Domain, occurring in the states of Acre, Rondônia, Tocantins, Piauí, Maranhão, Bahia, Sergipe, Distrito Federal, Mata Grosso do Sul, Mato Grosso, Goiás, Espírito Santo and Minas Gerais (BFG 2018; Flora do Brasil 2020).

15. Vanilla bahiana Hoehne, Arq. Bot. Estado São Paulo, 2(5): 108, t. 43. 1950.

Fig. 3j

Hemiepiphyte. Roots cylindrical, thin. Stem 0.7-0.9 cm diameter, green, cylindrical, between $11.3-17 \mathrm{~cm}$ long. Leaves $15.1-21.1 \times 2-3 \mathrm{~cm}$, flat, distributed along the stem, coriaceous, narrow-elliptical, apex acute, leaves present during flowering. Inflorescence $4.8-13 \mathrm{~cm}$ long, lateral, racemose, erect; floral bracts $0.5-0.9 \times 0.5-0.7$ $\mathrm{cm}$, ovate to lanceolate, apex acute. Flowers 6-9, resupinate; dorsal sepal $7.5-7.7 \times 0.9-1.3 \mathrm{~cm}$, oblanceolate, greenish yellow, apex acute; lateral sepals 7-7.3 × 1-1.3 cm, oblanceolate, greenish yellow, apex acute; petals 7.3-7.6 ×0.7-0.9 cm, oblanceolate, greenish yellow, apex acute; lip 
6.4-6.9 ×2-2.2 cm, infundibuliform, white, margin wavy, terminal callus $0.5-0.8 \mathrm{~cm}$ long, apex cuspid; column 5.3-5.5 cm long, pollinia 2, parallel. Fruit 1.1-1.4 × 6.2-8.1 cm, fusiform, elongate.

Material examined: São João do Sóter, Localidade Serra, 0502'79'S, 4344'48'W, 10.XII.2017, fl., M.S. de Oliveira 100 (HABIT). Caxias, Área de Proteção Ambiental do Inhamum, trilha do alambique, 0453'32'S, 43²5'35'W, 15.I.2018, fl., M.S. de Oliveira 101 (HABIT); localidade Primavera, 0450'32"S, 43²9'30'W, 29.I.2019, fl., M.S. de Oliveira 151 (MAR).

Vanilla bahiana in occasional in the area, it blooms between the months of January and December. It was collected in gallery forest, growing on the species Mangifera indica and Mimosa sp. (cat's claw). It differs from the other species of Vanilla in the area by its oblanceolate petals and sepals with acute apex and white lip.

Endemic to Brazil (Govaerts et al. 2019), it is distributed in the domains of Caatinga, Cerrado and Atlantic Forest, occurring in the states of Maranhão, Rio Grande do Norte, Paraíba, Pernambuco, Sergipe, Alagoas, Bahia, Distrito Federal, Espírito Santo, Minas Gerais, Rio de Janeiro and São Paulo (BFG 2018; Flora do Brasil 2020).

16. Vanilla palmarum (Salzm. ex Lindl.) Lindl., Gen. Sp. Orchid. Pl. 436. $1840 . \quad$ Fig.3k

Epiphyte. Roots cylindrical, thin. Stem 0.3$0.4 \mathrm{~cm}$ diam., green, cylindrical, internodes $5-11 \mathrm{~cm}$ long. Leaves 8.7-14 × 4.1-5.4 cm, flat, distributed along the stem, leathery, ovate, apex acute, leaves present during flowering. Inflorescence $4.5-5 \mathrm{~cm}$ long, lateral, racemose, erect; floral bracts 1.1-2 $\times 0.8-1.2 \mathrm{~cm}$ long, ovate, apex acute. Flowers 9-13, resupinate; dorsal sepal 4.7-4.8 ×0.9-1 cm, lanceolate, yellow, apex acute; lateral sepals 5-5.2 $\times 1-1.1 \mathrm{~cm}$, lanceolate, yellow, apex acute; petals 5-5.3 × 1.3-1.5 cm, oblanceolate, yellow, apex acute; lip 3.5-3.7 × 2.5-2.8 cm, infundibuliform, yellow, margin wavy, callus absent, apex bilobed; column 4-4.1 cm long, pollinia 2. Fruits not seen. Material examined: Caxias, povoado Cantinho, 0447'74"'S, 4319'50"W, 6.XI.2016, fl., M.S. de Oliveira 22 (HABIT); povoado Cantinho, 10.XI.2016, fl., M.S. de Oliveira 143 (HABIT); Área de Proteção Ambiental do Inhamum, trilha do alambique, 0452'39' $\mathrm{S}$, 4324'38'W, 16.I.2018, fl., M.S. de Oliveira 146 (MAR).

Vanilla palmarum in occasional in the area, blooms in the month of November. It was collected in babassu groves, growing on the species on $A$. speciosa and Mauritia flexuosa Mart. (buriti palm). It is distinguished from other species of Vanilla in the area by its epiphytic habit and lip without callus.
Widely distributed in South America (Govaerts et al. 2019) and Brazil, it is found in the Amazon Rainforest, Cerrado, Caatinga and Atlantic Forest domains, occurring in the states of Acre, Amazonas, Amapá, Pará, Roraima, Tocantins, Maranhão, Piauí, Paraíba, Pernambuco, Sergipe Alagoas, Bahia, Goiás, Mato Grosso and Mato Grosso do Sul (BFG 2018; Flora do Brasil 2020).

17. Vanilla pompona Schiede, Linnaea, 4: 573. 1829.

Fig. 31

Hemiepiphyte. Roots cylindrical, thin. Stem $1.1 \mathrm{~cm}$ diameter, green, cylindrical, $9.9-12.3 \mathrm{~cm}$ long. Leaves $17-17.8 \times 6.4-8 \mathrm{~cm}$, flat, leathery, distributed along the stem, oblong, apex acute, leaves present during flowering. Inflorescence 4-5 cm long, lateral, racemose, erect; floral bracts $1-1.4 \times 1-1.3 \mathrm{~cm}$, concave, oval to lanceolate, apex acute. Flowers 5-11, resupinate, yellow; dorsal sepal 7.5-9.8 × 0.8-1.4 cm, oblanceolate, yellow, apex obtuse; lateral sepals $6.7-8.5 \times 0.7-1.2 \mathrm{~cm}$, oblanceolate, yellow, obtuse apex; petals 6.5-9.2 $\times$ 0.8-1.3 cm, oblanceolate, yellow, apex obtuse; lip $6.7-8 \times 2.4-3 \mathrm{~cm}$, yellow, margin wavy, terminal callus $0.5-1 \mathrm{~cm}$ long, apex cuspidate; column $6.3-6.5 \mathrm{~cm}$ long, pollinia 2. Fruit $10-13 \times 1.8-2.5$ $\mathrm{cm}$, fusiform.

Material examined: Caxias, Área de proteção Ambiental Municipal do Inhamum, mata ciliar, trilha do Alambique, 04'53'31'S, 4325'34'W, 17.VII.2017, fl., M.S. de Oliveira 82 (HABIT); trilha do Alambique, 14.VIII.2018, fl., M.S. de Oliveira 135 (HABIT); 16.VIII.2018, fl., M.S. de Oliveira 136 (HABIT).

Vanilla pompona in rare in the study area, it blooms between the months of July and August. It was collected in the gallery forest, growing on a species of Mimosa (cat's claw). It differs from other species of Vanilla in the area by its oblanceolate petals and sepals and obtuse apex.

Widely distributed in South America (Govaerts et al. 2019) and Brazil, it is distributed in the Amazon Rainforest and Cerrado domains, occurring in the states of Amazonas, Amapá, Rondônia, Tocantins, Maranhão, Paraíba, Pernambuco, Goiás, Mato Grosso and Minas Gerais (BFG 2018; Flora do Brasil 2020).

\section{Acknowledgements}

To the Maranhão Foundation for Scientific and Technological Research and Development (FAPEMA), for granting the scholarship to the first author (process BM-02144/18); the research resource related to the Universal Project 
(0430/2015); and the National Council for Scientific and Technological Development (CNPq) (process n ${ }^{\circ} 407513 / 2018-3$ ).

\section{References}

Afonso EAL, Koch AK \& Costa JM (2016) Flora preliminar de Orchidaceae no município de Abaetetuba, Pará, Brasil. Biota Amazônia 6: 107118.

Aldeias Altas (2011) Relatório diagnóstico do município de Aldeias Altas. Available at <http://rigeo. cprm.gov.br/xmlui/bitstream/handle/doc/15324/ relaldeias_altas.pdf? sequence $=1>$. Access on 23 April $201 \overline{9}$.

Almeida A, Felix WJP, Andrade LA \& Feli LP (2007) A família Orchidaceae em inselbergues da Paraíba, Nordeste do Brasil. Biociências 5: 753-755.

Bastos CA \& Van den Berg C (2012) Flora da Bahia: Catasetum (Orchidaceae). Sitientibus série Ciências Biológicas 12: 83-89.

Batista JAN, Luciano BB \& Pellizzaro KF (2005) Orchidaceae da Reserva Ecológica do Guará, DF, Brasil. Acta Botanica Brasilica 19: 221-232.

Batista JAN, Silva JBF \& Bianchetti LB (2008) The genus Habenaria (Orchidaceae) in the Brazilian Amazon. Revista Brasileira de Botânica 31: 105-134.

BFG - The Brazil Flora Group (2018) Brazilian Flora 2020: innovation and collaboration to meet Target 1 of the Global Strategy for Plant Conservation (GSPC). Rodriguésia 69: 1513-1527.

Campacci MA\& Silva JBF (2009) Mormodes gurupiensis Campacci \& da Silva. Coletânea de Orquídeas Brasileiras 7: 237-241.

Caxias (2011) Decreto Municipal n. ${ }^{\circ} 2.943 / 2013$. Plano municipal de saneamento básico de Caxias (MA). Available at <http://rigeo.cprm.gov.br/ xmlui/bitstream/handle/doc/15431/rel-caxias. pdf? sequence=1>. Access on 23 April 2019.

Chase MW, Cameron KM, Freudenstein JV, Pridgeon AM, Salazar G, Van Den Berg C \& Schuiteman A (2015) An updated classification of Orchidaceae. Botanical Journal of the Linnean Society 177: 151-174.

Codó (2011) Relatório diagnóstico do Município de Codó. Available at <http://rigeo.cprm.gov. $\mathrm{br} / \mathrm{xmlui} / \mathrm{bitstream} / \mathrm{handle} / \mathrm{doc} / 15443 / \mathrm{relcodo}$. pdf? sequence $=1>$. Access on 23 April 2019.

Costa CF, Fonseca RS, Almeida DB, Oliveira MS, Oliveira DS \& Braga JHP (2017) Espécies utilizadas na arborização em praças do município de Caxias, Maranhão. Sociedade Brasileira de Arborização Urbana 12: 65-78.

Dressler RL (1993) Phylogeny and classification of the orchid family. Dioscorides Press. 314p.

IBGE - Instituto Brasileiro de Geografia e Estatística (2019) Available at <https://cidades.ibge.gov.br/ brasil/ma/sao-joao-do-soter/panorama>. Access on 23 April 2019.

IBGE - Instituto Brasileiro de Geografia e Estatística (2012) Manual Técnico da Vegetação Brasileira. Série Manuais Técnicos em Geociências 1, $2^{\text {a }}$ edição revista e ampliada. IBGE, Rio de Janeiro. 271p.

IMESC (2010) Anuário Estatístico do Maranhão. Vol. 4. Instituto Maranhense de Estudos Socioeconômicos e Cartográficos, São Luís. 791p.

Faria RT, Colombo RC, Oliveira LVR \& Camolesi MR (2016) Orquídeas do Gênero Catasetum no Brasil. Vol 1. Ed. Mecenas, Londrina. 160p.

Ferreira AWC, Lima MIS \& Pansarin ER (2010) Orchidaceae in the central portion of São Paulo state, Brazil. Rodriguésia 61: 243-259.

Ferreira AWC, Oliveira MS, Silva EO, Campos DS, Pansarin ER \& Guarçoni EAE (2017) Vanilla bahiana Hoehne and Vanilla pompona Schiede (Orchidaceae,Vanilloideae): two new records from Maranhão state, Brazil. Check List 13: 1131-1137.

Fidalgo O \& Bononi VLR (1989) Técnicas de coleta, preservação e herborização de material botânico. Instituto de Botânica, São Paulo. 62p.

Flora do Brasil 2020 em construção. Instituto de Pesquisas Jardim Botânico do Rio de Janeiro. Available at $<$ http://floradobrasil.jbrj.gov.br/>. Access on 23April 2019.

Govaerts R, Pfahl J, Campacci MA, Holland BD, Tigges H, Shaw J, Cribb P, George A, Kreuz K \& Wood J (2019) World checklist of Orchidaceae. The board of trustees of the Royal Botanic Gardens, Kew. Available at $<$ http://apps.kew.org/wcsp/>. Access on 31 July 2019.

Hall CF, Klein VLG \& Barros F (2013) Orchidaceae of Caldas Novas, state of Goiás, Brazil. Rodriguésia 64: 685-704.

Koch AK \& Silva CA (2012) Orquídeas nativas de Mato Grosso. Editora Carlini \& Caniato, Cuiabá. 112p.

Köppen W (1948) Climatologia. Fondo de Cultura Econômica, México. 496p.

Lacerda K \& Silva JBF (1998) Boletim do Herbarium Bradeanum (Bradea) 8: 69-72.

Maranhão (2011) Plano de ação para prevenção e controle do desmatamento e das queimadas no Estado do Maranhão, São Luís. 110p.

Marinho LC \& Azevedo CO (2014) Orchidaceae na Reserva do Poço Escuro, Vitória da Conquista, Bahia, Brasil. Sitientibus série Ciências Biológicas 13:1-14.

Monteiro SHN, Silva TC, Santos LAS, NascimentoJúnior JE \& Prata APN (2012). Survey of Orchidaceae from the State of Sergipe, Brazil. Biota Neotropica 12: 167-175.

Oliveira MS, Ferreira AWC, Lopes JRS, Reis JR, Silva Junior WR \& Costa JA (2017) Espécies vegetais presentes em praças e avenidas do município de Aldeias Altas, Maranhão, Brasil. Sociedade Brasileira de Arborização Urbana 12: 13-22. 
Oliveira MS, Oliveira HC, Ferreira AWC, Silva Junior WR \& Silva MJC (2019) Levantamento florístico das espécies utilizadas no paisagismo do município de São João do Sóter, Maranhão, Brasil. Enciclopédia Biosfera 16: 981-994.

Oliveira MS, Silva EO, Ferreira AWC \& Guarçoni EAE (2016) Conhecimento e uso tradicional das espécies madeireiras e medicinais utilizadas no município de Aldeias Altas, Maranhão, Brasil. Enciclopédia Biosfera 13: 1116-1173.

Pabst GFJ \& Dungs F (1975) Orchidaceae Brasilienses I. Brucke-Verlag Kurt Schmersow, Hildesheim. 408p.

Pabst GFJ \& Dungs F (1977) Orchidaceae Brasilienses II. Brucke-Verlag Kurt Schmersow, Hildesheim. 418p.

Pessoa E \& Alves M (2011) Orchidaceae Juss. na Serra de Itabaiana, Sergipe, Brasil. Caatinga 24: 102-114.

Pessoa E \& Alves M (2012) Flora da Usina São José, Igarassu, Pernambuco: Orchidaceae. Rodriguésia 62: 341-356.

Pessoa E \& Alves M (2014) Orchidaceae em afloramentos rochosos do estado de Pernambuco, Brasil. Rodriguésia 65: 717-734.

Pessoa E \& Alves M (2015) Synopsis of Orchidaceae from Serra do Urubu: an area of montane forest, Pernambuco State, Brazil. Hoehnea 42: 109-133.

Rocha AES \& Silva JBF (2001) Variações morfológicas do labelo de Catasetum barbatum (Lindl). (Orchidaceae). Acta Amazonica 31: 365-373.

Rodrigues ML, Mota NFO, Viana PL, Koch AK \& Secco RS (2019) Vascular flora of Lençóis Maranhenses National Park, Maranhão state, Brazil: checklist, floristic affinities and phytophysiognomies of restingas in the municipality of Barreirinhas. Acta Botanica Brasilica 33: 498-516.

Rodriguez DP, Barros F, Junior GAD \& Bortolotto IM (2009) Levantamento da família Orchidaceae no Morro Santa Cruz, Municípios de Corumbá e Ladário, Mato Grosso do Sul, Brasil. Hoehnea 36: 613-636.

Romand-Monnier F (2013a) Catasetum barbatum. Lista Vermelha de Espécies AmeaçadasdaIUCN 2013:e. T44392583A44525362. Available at <http:// dx.doi.org/10.2305/IUCN.UK.2013-1.RLTS. T44392583A44525362.en>. Access on 11 July 2019.

Romand-Monnier F (2013b) Oeceoclades maculata. Lista Vermelha de Espécies Ameaçadas da IUCN 2013:
e.T44392733A44514773. Available at <http:// dx.doi.org/10.2305/IUCN.UK.2013-1.RLTS. T44392733A44514773.en>. Access on 11 July 2019.

Santos FA \& Aquino CMS (2016) Panorama da desertificação no nordeste do Brasil: Características e suscetibilidades. Interespaço 2: 144-161.

São João do Sóter (2011) Relatório diagnóstico do município de São João do Sóter. Available at $<$ http://rigeo.cprm.gov.br/xmlui/bitstream/handle/ doc/15629/rel_sao_joao_soter.pdf? sequence $=1>$. Access on 23 April 2019.

Silva MFF \& Oliveira AT (1999) Catasetum seccoi. Catasetum carrenhianum e Catasetum albuquerquei: Novas espécies de Orchidaceae para o estado do Maranhão, Brasil. Boletim do Museu Paraense Emilio Goeldi 15: 105-114.

Silva MFF \& Oliveira AT (2000) Catasetum rigidium, Carasetum bifidum, Catasetum palmeirinhense: Novas espécies de Orchidaceae para o estado do Maranhão, Brasil. Boletim do Museu Paraense Emilio Goeldi 16: 151-161.

Silva MFF, Silva JBF \& Feiler JM (1999). Orchidaceas do estado do Maranhão, Brasil. Acta Amazonica 29: 381-393.

Stella A (2011) Plano de prevenção e controle do desmatamento e queimadas do Maranhão. SEMA, São Luís. 120p.

The Plant List (2019) A working list of all plant species. Available at $<$ http://www.theplantlist.org/>. Access on 23 April 2019.

Thiers B [continuously updated] Index herbariorum: a global directory of public herbaria and associated staff. New York Botanical Garden's Virtual Herbarium. Available at <http://sweetgum.nybg.org/ science/ih/>. Accessed on 23 April 2019.

Tropicos (2019) Missouri Botanical Garden. Available at $<$ http://www.tropicos.org/>. Access on 23 April 2019.

Vieira TL \& Barros F (2017) Orchidaceae from Serra do Ouro Branco, state of Minas Gerais, Brazil. Rodriguésia 68: 691-747.

Vieira TL, Barros F \& Roque N (2014) Orchidaceae no Município de Jacobina, estado da Bahia, Brasil. Hoehnea 41: 469-482. 